\title{
Introduction to the Special Collection on the Media
}

\author{
Eugene V. Beresin ${ }^{1} \cdot$ Steven C. Schlozman ${ }^{1}$
}

Received: 19 March 2019 / Accepted: 2 April 2019 / Published online: 26 April 2019

(C) Academic Psychiatry 2019

Interaction with media is ubiquitous in the society. Few can escape its powerful and pervasive impact. Indeed, for many of us, media is a daily staple. Nationally and abroad, we increasingly choose what media to consume and when to consume it in much the same way that we consume our meals.

This change in media use is not necessarily bad. Access to information, organizations, friends, and colleagues is instantaneous. Communication has become fluid, rapid, and, if carefully executed, efficient and effective.

As psychiatric professionals, we-the authors-interact with media for a range of reasons. We gather clinical and scientific research. We access information about medication interactions simply by logging on to the computer. We convey our thoughts and experiences to colleagues and the public through blogs, tweets, and podcasts, as well as through more traditional media formats.

In this special collection, it is our goal as editors to provide discussions and guidelines for the many ways media can be used in professional psychiatric settings. The articles are highly pragmatic, focusing on the means through which interactions with media promote excellence in patient care and public education but at the same time are fraught with the inherent liabilities that are characteristic of media engagement. To this end, the explicit goal of every article in the collection is to outline how different kinds of media are best utilized throughout the professional actions of an academic psychiatrist's life.

Schlozman et al. [1] review the importance of psychiatric leaders' need to understand and engage modern media. As senior representatives of the field of psychiatry, leaders' mission, vision, and objectives need to be clearly delineated to the public and to national and international organizations.

Louie and colleagues [2] provide detailed guidance on how psychiatrists prepare for and perform in print, television,

Eugene V. Beresin

eberesin@partners.org

1 Harvard Medical School, Boston, MA, USA radio, and Internet interviews. While psychiatrists are often called upon to weigh in on tragic, even horrifying, events, there are a myriad of opportunities for those interested in public outreach to use media as a vehicle for basic mental health education, destigmatization of mental illness, and advocating for changes in public policy, access to care, and social determinants of mental health and illness.

Morris [3] focuses on the professional risks psychiatrists take and the benefits they garner when they choose to write for media outlets. His paper includes practical advice to ensure that narratives are well researched, representative of personal opinions as well as that of institutions, and thoughtfully constructed. It is important to keep in mind at all times that participation in modern media coverage leaves a digital footprint that cannot be taken back.

Davidson et al. [4] explore the pedagogical opportunities that podcasts bring to classrooms and supervision hours. The narrative and emotionally powerful nature of podcasts, coupled with the immense popularity that podcasts currently enjoy, uniquely positions these kinds of media for a much greater role in psychiatric education.

Finally, Gabbard [5] explores the complex relationship between digital media and professionalism. He focuses particularly on patient care, considering the ways in which clinicians and patients may use (or misuse) the digital world in the course of treatment. Important issues include privacy for both doctor and patient and the many ways digital media can enhance or interfere with care. He wisely advocates that education in digital professionalism should start as early as medical school, and he discusses the benefits and pitfalls of Internet searches by doctors and patients researching each other. Ultimately, he notes the need for hospitals, clinics, and academic centers to develop policies regarding ethical and professional digital behavior.

The rapid explosion of media in its many forms has potentially outpaced understanding of its appropriate professional use. In this sense, psychiatric educators are constantly developing new appreciations for the roles that they can play in this new media environment. While media may be seen as a 
blessing and a curse, it is the editors' hope that this collection of articles will enhance readers' appreciation of the need to harness media in the most beneficial ways for patient care and public health.

\section{Compliance with Ethical Standards}

Disclosures On behalf of all authors, the corresponding author states that there is no conflict of interest.

\section{References}

1. Schlozman S, Carron M, Beresin E. Why psychiatrist leadership should understand and engage modern media. Acad Psychiatry 2019. https://doi.org/10.1007/s40596-019-0161-7.
2. Louie AK, Beresin EV, Schlozman S, et al. The psychiatrist being interviewed by the media. Acad Psychiatry (2018). https://doi.org/ 10.1007/s40596-018-0970-y.

3. Morris N. The psychiatrist writing for popular media. Acad Psychiatry (2018). https://doi.org/10.1007/s40596-018-0961-z.

4. Davidson S, Grunau Z, Marcovitz D, et al. Narrative podcasts as a teaching tool in psychiatry. Acad Psychiatry 2019. https://doi.org/10. 1007/s40596-019-0162-6.

5. Gabbard G. Digital professionalism. Acad Psychiatry (2018). https:// doi.org/10.1007/s40596-018-0994-3.

Publisher's Note Springer Nature remains neutral with regard to jurisdictional claims in published maps and institutional affiliations. 